\title{
Rumusan Pidana Dan Pemidanaan Tindak pidana Korupsi Yang Merugikan Keuangan Negara Serta Permasalaan Dalam Penerapannya
}

\author{
Hulman Siregar ${ }^{*}$
}

Auditor Madya pada Badan Pengawasan Keuangan dan Pembangunan, Mahasiswa Program Magister (S2) Ilmu Hukum Fakultas Hukum UNISSULA Semarang, email : hstregar@gmail.com

\begin{abstract}
ABSTRAK
Korupsi telah terjadi pada semua lini sektor kegiatan pada Lembaga dan Institusi Negara, bahkan telah dikategorikan sebagai kejadian yang luar biasa (extra ordinary crime). Kondisi ini menimbulkan dampak buruk bagi pelaksanaan pembangunan nasinal yang berkelanjutan untuk meningkatkan kesejateraan masyarakat, karena anggaran dana Negara baik pusat maupun daerah yang dapat digunakan untuk membangun sarana prasarana pelayanan publik seperti layanan kesehatan, pendidikan, bantuan sosial berupa sandang pangan menjadi berkurang karena perbuatan korupsi. Perserikatan Bangsa Bangsa menaruh perhatian atas kejadian dan dampak perbuatan korupsi berupa konvensi (United Nation Convention Againts Corruption) yang disepakati oleh Negara Negara peserta konvensi. Pencegaan dan penindakan melalui penegakan hukum harus dilakukan secara komprehensif sehingga penerapan penegakan hukumnya efektif. Penegakan hukum atas perbuatan korupsi yang terjadi saat ini seharusnya dilakukan mulai saat perencanaan peraturan penerapan peraturan dan pelaksanaan peraturan, sehingga penerapan dan pelaksanaan peraturan perundang-undangan dalam rangka penegakan hukum menjadi efektif. Untuk mengetahui penegakan hukum atas tindak pidana korupsi khususnya yang merugikan Negara dilakukan analisis dan evaluasi Undang Undang No 31 Tahun 1999 sebagaimana telah diubah dengan Undang Undang No 2 Tahun 2001. Simpulan analisis dan evaluasi sebagai bahan masukan dan pertimbangan dalam merumuskan peraturan perundang-undangan pada masa yang akan datang.

Kata kunci, Sinkronisasi,perencanaan,penerapan, dan pelaksanaan.
\end{abstract}

\section{Abstract}

Corruption has occurred in all lines of activity in Institutions and State Institutions, even categorized as extraordinary crime. This condition has adverse impacts on the implementation of sustainable development to improve the welfare of the community, since the state budget funds, both central and regional, which can be used to build public service infrastructure such as health services, education, social assistance in the form of food clothing, are reduced by corruption. The United Nations is concerned with the incidents and effects of a United Nation Convention Against Corruption agreed upon by States Parties to the Convention. Enforcement through law enforcement should be comprehensive so that the activities of its law enforcement is effective. The current law enforcement of corruption should be done from the time of planning the implementation of regulations and the execution of implementation of regulations, so that the implementation and enforcement of legislation in the framework of law enforcement becomes effective. To know the law enforcement of corruption crime especially detrimental to State done analysis and evaluation of Law No 31 Year 1999 as already 
amended by Law No. 2 Year 2001. Conclusion of analysis and evaluation as input and consideration in formulating legislation in period which will come.

Keywords, Sync, planning, implementation, and execution

\section{PENDAHULUAN}

Korupsi adalah perbuatan yang dapat menimbulkan kerugian bagi banyak pihak bahkan dapat mempengaruhi eksistensi dan perkembangan kemajuan serta kesejahteraan masyarakat suatu negara. Menurut Fockema Andrea kata korupsi berasal dari bahasa latin corruptio atau corruptus (Webster Student Dictionary:1960). Kemudian muncul dalam bahasa Inggris dan Prancis corruption, dalam bahasa Belanda Korruptie dan dari bahasa Belanda inilah kata itu turun ke Bahasa Indonesia yaitu korupsi.

Korupsi terjadi di semua negara di seluruh dunia, perbedaannya hanyalah seberapa mewabahnya korupsi tersebut di satu negara, dibandingkan negara lain. ${ }^{1}$ Adolfo Beria memandang korupsi sebagai fenomena dunia, keberadaanya mengikuti sejarah manusia itu sendiri. ${ }^{2}$ Lebih lanjut Adolfo Beria menyatakan :

"There is no primordial indigenous culture without its phenomena of corruption;there is no system (from that USA to that of Japan)which is free from vast areas of corruption; there is no centre of government (from the prairies of America to the communist collectivizations) which has not been vitiated or distorted by corruption; there is no religion (Eastern, Judaic, Christian or Islamic) which has not had to confront evils connected to corruption; there is no Empire (be it Persian, Roman, British or Soviet) which has no experienced and has not been damaged by corruption". ${ }^{3}$ ( tidak ada budaya asli primordial tanpa fenomena yang korupsi;tidak ada sistem dari Amerika Serikat sampai Jepang yang bebas dari wilayah korupsi; tidak ada pusat pemerintahan (dari padang rumput Amerika sampai ke wilayah komunis) yang belum dirusak atau terganggu oleh korupsi; tidak ada agama (timur, Yahudi, Kristiani atau Islam) yang tidak melawan kejahatan korupsi; tidak ada kerajaan (Persia,Romawi,Ingris atau Soviet) tidak memiliki pengalaman dan yang tidak dirusak oleh korupsi)

Perilaku korupsi terjadi dimana-mana, baik di antara sesama kerabat, dalam sistem pemerintahan yang demokratis maupun komunis, baik pada lembaga keagamaan, fenomena korupsi dapat terjadi. Hampir pada setiap negara, khususnya pada masa awal pemerintahan terbentuknya suatu negara perilaku korup dari penyelenggara negara dan kroninya marak terjadi. Fungsi saling mengawasi diantara lembaga negara (check and balance) belum berjalan sebagaimana mestinya. Hal ini dapat dilihat dari sejarah perjalanan dan perkembangan negara-negara yang tingkat persepsi korupsinya saat ini rendah yang digolongkan sebagai negara maju. Korupsi senantiasa berkembang dalam kegelapan totalitarisme dan kediktatoran rezim-rezim yang membagi kekuasaannya kepada segelintir orang yang

\footnotetext{
${ }^{1}$ Theodorus.M.Tuanakotta, 2010, Akuntasi Forensik \& Audit Investigatif, Ed. 2, Jakarta: Salemba Empat, hal. 224.

${ }^{2}$ Adolfo Beria, Global Strategi Against Corruption, dalam Responding to Corruption: Social Defence, Corruption, and the Protection of Public Administration and The Independence of Justice, up date documens on the XIII International Conggres on Social Defence, Lecce Italy 1996, diedit oleh Paolo Bernasconi, 2000, hal.23.

${ }^{3}$ Ibid.
} 
tidak bertanggungjawab. ${ }^{4}$

Bentuk-bentuk perbuatan korupsi semakin berkembang sesuai dengan kemajuan dan perkembang zaman baik secara kualitas maupun kuantitas. Pada masa penjajahan kolonial Belanda korupsi masih sangat sederhana, demikian juga pada masa awal pemerintahan Indonesia seperti terlihat dari perumusan pasal-pasal KUHAP. ${ }^{5}$ Tidak berlebihan jika pengertian dan modus korupsi selalu berkembang dan berubah sesuai dengan perubahan zaman. ${ }^{6}$ Kondisi ini menjadi perhatian dari negara negara anggota Perserikatan Bangsa Bangsa yang ditindaklanjuti dengan Resolusi Nomor 58/4 tanggal 31 Oktober 2003 dan juga telah diratifikasi dengan Undang Undang Republik Indonesia Nomor 7 Tahun 2006 tentang pengesahan United Nations Againts Corruption, 2003. ${ }^{7}$

Pembuktian unsur kerugian keuangan Negara dalam penanganan kasus kasus tindak pidana korupsi yang merugikan Negara dalam sistem peradilan pidana merupakan kegiatan yang paling dominan, mulai dari tahapan penelitian, penyidikan, penuntutan sampai pemeriksaan perkara pada sidang pengadilan sasaran utamanya adalah untuk membuktikan bahwa tindak pidana korupsi yang merugikan Negara telah terjadi dan pelakunya adalah tersangka/terdakwa yang didukung oleh alat bukti. Alat bukti ini nanti sebagai pedoman dan pertimangan hakim dalam memutus suatu perkara korupsi khususnya tindak pidana korupsi yang merugikan Negara dalam menjatuhkan pidana baik pidana pokok maupun pidana tambahan.

Penghitungan kerugian keuangan negara dipengaruhi oleh konsep dan perumusan pengertian keuangan negara. Sesuai dengan perkembangan ilmu keuangan negara terdapat beberapa pengertian dan rumusan keuangan negara menurut para ahli yaitu pengertian dalam arti luas dan pengertian dalam arti sempit. Selain itu terdapat beberapa metode penghitungan kerugian negara yang hasil penghitungannya berbeda dengan menggunakan metode yang satu dengan metode yang lainnya. Hal ini dapat menimbulkan perbedaan penghitungan kerugian keuangan negara pada kasus tindak pidana korupsi yang sama antara ahli auditor yang diajukan oleh penyidik dan ahli auditor yang meringankan terdakwa.

Berdasarkan latar belakang yang telah diuraikan diatas, penulis merumuskan beberapa permasalahan yang akan menjadi fokus bahasan dalam penelitian hukum ini, yaitu:

a. Bagaimana Proses dan Pengaturan Pemidanaan Tindak Pidana Korupsi yang merugikan keuangan Negara dalam Undang-Undang Nomor 31 Tahun 1999?

b. Bagaimana penerapan pemidanaan Tindak Pidana Korupsi yang merugikan keuangan Negara dalam rangka pengembalian keuangan negara?

\section{Metode Penelitian}

Penelitian hukum merupakan suatu kegiatan ilmiah yang didasarkan pada metode, sistematika dan pemikiran tertentu yang bertujuan untuk mempelajari suatu hal atau beberapa gejala hukum

\footnotetext{
${ }^{4}$ Darwan Prints, 2002, Pemberantasan Tindak Pidana Korupsi, PT Citra Aditya Bakti, Bandung, , hal.9

${ }^{5}$ Ibid, hlm. 7

${ }^{6}$ Martiman Prodjohamidjojo, 2001,Penerapan Pembuktian Terbalik dalam Delik Korupsi, CV. Mandar Maju, Bandung, hal. 7

7 Juni Sjafrien Jahja, 2013, Prinsip Kehati-hatian dalam Memberantas Manajemen Koruptif pada Pemerintahan \& Korporasi,visimedia,Jakarta ha.10.
} 
tertentu dengan jalan menganalisisnya. ${ }^{8}$ Pendekatan dan bahan hukum yang digunakan dalam penulisan ini disesuaikan dengan latar belakang dan rumusan masalah yang terlah diuraikan sebelumnya.

Penelitian untuk mendukung penulisan ini merupakan penelitian normatif dengan cara meneliti bahan kepustakaan atau data sekunder. Penelitian normatif merupakan penelitian hukum yang dilakukan dengan cara meneliti bahan pustaka atau data sekunder. ${ }^{9}$ Dilihat dari perspektif sifatnya penelitian ini digolongkan kepada deskriptif-analitis, dimana dalam penelitian ini penulis akan menguraikan teori hukum pembuktian dan hukum acara pidana yang mengatur tentang pembuktian, alat bukti, unsur delik pidana korupsi, keuangan negara, metode penghitungan kerugian negara Tindak Pidana Korupsi dalam Sistem Peradilan Pidana Indnesia..

Spesifikasi penelitian ini adalah deskriptif analitis, dimana penelitian ini diharapkan akan memberikan gambaran secara rinci mengenai proses pembuktian dan penghitungan kerugian Negara tindak pidana korupsi yang merugikan keuangan Negara dalam Sistem Peradilan Pidana.

Sebuah penelitian harus menggunakan data. ${ }^{10}$ Data yang digunakan dalam suatu penelitian dibedakan kedalam dua jenis yaitu, data primer dan data sekunder. Data primer (primary data atau basic data) adalah data yang diperoleh langsung dari perilaku masyarakat. Sedangkan data sekunder adalah data dari bahan pustaka, antara lain mencakup dokumen-dokumen resmi, buku-buku, hasil penelitian yang berwujud laporan, buku harian, dan sebagainya. ${ }^{11}$ Sesuai dengan jenis penelitian dalam penulisan ini adalah penelitian hukum normatif, maka data yang digunakan lebih banyak data sekunder.

Data sekunder yang digunakan sebagai bahan hukum dalam penulisan ini terdiri dari: 1) Bahan hukum primer yang terdiri dari: Undang-Undang No.8 Tahun 1981 tentang Hukum Acara Pidana, Undang-Undang No.31 Tahun 1999 tentang Pemberantasan Tindak Pidana Korupsi, Undang-Undang No.17 Tahun 2003 tentang Keuangan Negara, Undang-Undang No.1 Tahun 2004 tentang Perbendaharaan Negara; 2) Bahan Hukum Sekunder antara lain terdiri dari: Hasil karya ilmiah berupa, tesis dan disertasi yang berhubungan dengan keuangan negara dan tindak pidana korupsi, Buku-buku mengenai alat bukti menurut KUHAP, keuangan negara dan kerugian negara, akuntasi forensik, audit dan bukti audit serta metode dalam menghitung kerugian, Karya ilmiah berupa tulisan dalam jurnaljurnal ilmiah maupun media cetak yang berhubungan dengan alat bukti dan pembuktian tindak pidana korupsi, keuangan negara dan kerugian negara; 3) Bahan Hukum Tertier antara lain terdiri dari: Kamus Besar Bahasa Indonesia, Kamus Hukum.

Penulisan makalah ini dilakukan dengan menggunakan penelitian hukum normatif yang menggunakan data sekunder sebagai data utama dalam menganalisis permasalahan. Tehnik pengumpulan data yang digunakan dalam penelitian ini adalah Studi kepustakaan dengan

\footnotetext{
${ }^{8}$ Sri Mamudji, dkk.. 2005, Metode Penelitian dan Penulisan Hukum. Badan Penerbit Fakultas Hukum Universitas Indonesia, Jakarta, hal. 18.

${ }^{9}$ Soerjono Soekanto dan Sri Mamudji, 2003, Penelitian Hukum Normatif : Suatu Tinjauan Singkat, PT RajaGrafindo Persada, Jakarta,.hal.13.

${ }^{10}$ Husein Umar, 2005, Metode Penelitian Untuk Makalah dan Tesis Bisnis, PT RajaGrafindo Persada, Jakarta, hal.41.

${ }^{11}$ Soekanto, Soerjono, 2006, Pengantar Penelitian Hukum, Universitas Indonesia(UI Press),Jakarta, hal.12.
} 
pengumpulan bahan-bahan hukum primer, sekunder dan tertier yang diperoleh dari bahan-bahan kepustakaan berupa peraturan perundang-undangan, peraturan dan putusan pengadilan, buku, majalah dan artikel serta Laporan Hasil Audit Investigatif penghitungan kerugian keuangan negara yang relevan dengan pokok permasalahan yang dibahas.

\section{HASIL PENELITIAN DAN PEMBAHASAN}

Permasalahan korupsi di Indonesia sejak masa orde lama sampai dengan masa reformasi mengalami perkembangan sesuai dengan perkembangan masyarakat dan teknologi informasi, yang diikuti oleh perubahan dan penyesuaian undang-undang tentang pemeberantasan korupsi di Indonesia sesuai dengan perkembangan modus kejadian perbuatan korupsi. Masalah korupsi di Indonesia sudah merupakan persoalan yang komplek dan terjadi secara meluas di seluruh sisi kehidupan. ${ }^{12}$ Hasil survey dan penelitian yang dilakukan oleh beberapa media dan lembaga non pemerintah pemerhati korupsi menunjukkan bahwa tingkat korupsi di Indonesia masih tinggi. Hal ini dapat dilihat dari indeks persepsi korupsi (corruption perceptions index) Indonesia tahun 2009 menurut Transparency International (TI) 2,8 yaitu peringkat 111 dari 180 negara yang disurvey. Selain itu menurut hasil survey atas pelaku bisnis yang dipublikasikan oleh perusahaan konsultan "Political \& Economic Risk Consultancy" (PERC) pada Jakarta Kompas.Com Senin 8 Maret 2010 menunjukkan bahwa Indonesia merupakan negara yang paling korup dari 16 negara di Asia Pasifik yang menjadi tujuan investasi para pelaku bisnis.

Selain hasil survey yang menunjukkan bahwa Indonesia digolongkan sebagai negara yang tingkat korupsinya tinggi, fakta lainnya yang mendukung hasil survey tersebut adalah banyak pejabat publik yang terlibat dalam kasus korupsi. Menurut Kompas.com tanggal 17 Januari 2011, bahwa 17 orang dari 33 Gubernur seluruh Indonesia jadi tersangka kasus tindak pidana korupsi, yaitu lebih dari 50\% gubernur dan 138 Orang dari 497 Bupati/Walikota seluruh Indonesia dinyatakan sebagai tersangka Kasus Korupsi. Dari informasi tersebut bahwa 155 kepala daerah jadi tersangka kasus tindak pidana korupsi, dan tidak menutup kemungkinan akan terus bertambah sesuai dengan perubahan peta kekuatan politik pada pemerintahan maupun pada legeslatif.

Menurut catatan Indonesian Corruption Watch (ICW) "Sepanjang semester I 2016, aparat penegak hukum berhasil menaikkan status kasus dari penyelidikan ke penyidikan sebanyak 210 kasus di mana kerugian negara mencapai Rp 890,5 miliar dan suap Rp 28 miliar, SGD 1,6 juta, dan USD 72 ribu," . Kejaksaan menangani 133 perkara, kepolisian 59 perkara, dan KPK 18 perkara. Kejaksaan paling banyak menangani kasus dengan jumlah kerugian negara Rp 473 miliar dan suap Rp 14 juta. "Kepolisian menangani 59 kasus korupsi yang timbulkan kerugian negara Rp 252,2 miliar. Sementara itu KPK menangani 18 kasus yang menimbulkan kerugian negara Rp 164 miliar dan nilai suap Rp 28 miliar, SGD 1,6 juta, dan USD 72 ribu. ${ }^{13}$ Hasil kajian Laboratorium Ilmu Ekonomi Universitas Gadjah Mada (UGM), nilai kerugian negara akibat tindak pidana korupsi di Indonesia selama 2001-2015 mencapai Rp203,9 triliun.juga menghitung hukuman berupa denda dan sita aset hanya terkumpul

\footnotetext{
${ }^{12}$ Puslitbang Kejaksaan Agung R.I, Studi tentang Peranan Alat Bukti Keterangan Ahli Dalam Penanganan Perkara Tindak Pidana Korupsi, 2008

${ }^{13}$ https://news.detik.com/berita/3285348/icw-500-orang-jadi-tersangka-kasus-korupsi-sepanjang-januari-juni-2016.
} 
Rp21,26 triliun. Jumlah nilai kerugian tersebut baru dari kasus kasus tindak pidana korupsi yang terungkap oleh aparat penegak hukum dan perbuatan tindak pidana korupsi yang tidak terungkap jauh lebih besar.

Dampak yang diakibatkan perbuatan korupsi yang terjadi disegala bidang sangat berbahaya bagi individu, kelompok individu, organisasi, masyarakat, institusi, bahkan bangsa dan negara. Dampak tersebut dapat dirasakan seketika maupun secara perlahan-lahan namun pasti. Akumulasi akibat korupsi pada tingkat tertentu dapat mengancam kelangsungan pemerintahan suatu negara, sedangkan bagi organisasi selain menimbulkan kerugian keuangan juga berdampak tidak tercapainya tujuan organisasi. ${ }^{14}$ Dampak yang nyata atas perbuatan korupsi dapat dilihat dari terhambatnya pertumbuhan investasi penanaman modal dalam negeri maupun penanaman modal luar negeri yang diperlukan dalam pembangunan perekonomian negara, buruknya kualitas pelayanan publik, serta terbatasnya sarana prasarana bagi masyarakat, karena bocornya dana yang seharusnya digunakan untuk memelihara dan meningkatkan pelayanan bagi masyarakat.

Untuk mengatasi kondisi tersebut diperlukan upaya penegakan hukum berupa pencegahan maupun penindakan. Apakah upaya penegakan hukum khususnya berupa penindakan terhadap kasuskasus tindak pidana korupsi yang merugikan keuangan Negara telah didukung oleh pranata hukum dan bagaimana delik itu dirumuskan, pidana dan pemidanaannya.

\section{Unsur Delik Tindak Pidana Korupsi yang Merugikan Keuangan Negara}

Jenis tindak pidana korupsi dikelompokkan kedalam beberapa kelompok antara lain yaitu kerugian keuangan negara. Pasal dalam UU No. 31 Tahun 1999 jo No. 20 Tahun 2001 yang terkait dengan tindak pidana korupsi kerugian negara adalah Pasal 2 dan 3. Unsur atau elemen delik tindak pidana korupsi yang terkait dengan Pasal 2 dan 3 UU No. 31 Tahun 1999 jo No. 20 Tahun 2001 dapat dilihat dan diturunkan dari rumusan pasal.

Pasal 2 ayat (1) ;

Setiap orang yang secara melawan hukum melakukan perbuatan memperkaya diri sendiri atau orang lain atau suatu korporasi yang dapat merugikan keuangan negara atau perekonomian negara, dipidana dengan pidana penjara seumur hidup atau pidana penjara paling singkat 4 (empat) tahun dan paling lama 20 (dua puluh) tahun dan denda paling sedikit Rp 200.000.000,00 (dua ratus juta rupiah) dan paling banyak 1.000.000.000,00 (satu miliar rupiah).

Bertitik tolak pada ketentuan Pasal 2 di atas dapat ditarik unsur-unsur (bestanddelen) sebagai berikut: ${ }^{15}$

1. Setiap orang;

2. Perbuatan memperkaya sendiri atau orang lain;

3. Perbuatan tersebut sifatnya melawan hukum;

4. Dapat merugikan keuangan negara atau perekonomian negara.

Pasal 3;

\footnotetext{
${ }^{14}$ Pedoman Teknis,2010, Fraud Control Plan , Deputi Bidang Investigasi BPKP Jakarta, ha.23

${ }^{15}$ Lilik Mulyadi, Tindak Pidana Korupsi di Indonesia: Normatif, Teoritis, Praktik dan Masalahnya, Cet. Kedua, (Bandung: PT Alumni, 2011), hal. 80-89.
} 
"Setiap orang yang dengan menguntungkan diri sendiri atau orang lain atau suatu korporasi, menyalah-gunakan kewenangan, kesempatan, atau sarana yang ada padanya karena jabatan atau kedudukan yang dapat merugikan keuangan negara atau perekonomian negara, dipidana dengan pidana penjara seumur hidup atau pidana penjara paling singkat 1 (satu) tahun dan atau denda paling sedikit Rp 50.000.000,00 (lima puluh juta rupiah) dan paling banyak Rp 1.000.000.000,00 (satu milliar rupiah)

Merujuk pada uraian Pasal 3 tersebut di atas dapat ditarik unsur-unsur (bestanddelen) deliknya sebagai berikut: ${ }^{16}$

1. Dengan tujuan menguntungkan diri sendiri atau orang lain atau suatu korporasi;

2. Menyalahgunakan kewenangan, kesempatan atau sarana yang ada padanya karena jabatan atau kedudukan;

3. Perbuatan tersebut dapat merugikan keuangan negara atau perekonomian negara.

Uraian di atas baik Pasal 2 dan Pasal 3 salah satu unsur deliknya adalah dapat merugikan keuangan negara atau perekonomian negara. Unsur delik dapat merugikan keuangan negara atau perekonomian negara, kata dapat sebelum frasa merugikan keuangan negara atau perekonomian negara diuraikan dalam penjelasan Pasal 2 ayat (1) yaitu: kata dapat sebelum frasa merugikan keuangan negara atau perekonomian negara menunjukkan bahwa tindak pidana korupsi merupakan delik formal, yaitu adanya tindak pidana korupsi cukup dengan dipenuhinya unsur-unsur perbuatan yang sudah dirumuskan bukan dengan timbulnya akibat. ${ }^{17}$ Maka adanya kerugian keuangan negara atau kerugian perekonomian negara tidak harus sudah terjadi karena yang dimaksud dengan delik formil adalah delik yang dianggap telah selesai dengan dilakukannya tindakan yang dilarang dan diancam dengan hukuman oleh undang-undang. ${ }^{18}$

Timbul pertanyaan apakah kerugian keuangan negara atau perekonomian negara jumlah dan nilainya harus pasti atau dapat berupa potensi terjadinya kerugian keuangan negara? Pandangan ahli umunya terbagi dalam dua kubu dalam menjawab pertanyaan ini yaitu: ${ }^{19}$

Kubu pertama mengatakan bahwa potensi kerugian negara sudah dapat dikategorikan sebagai telah terjadi kerugian negara. Hal ini karena kata dapat sebelum frase merugikan keuangan negara atau perekonomian negara menunjukkan, bahwa tindak pidana korupsi ini merupakan delik formil, yaitu adanya tindak pidana korupsi cukup dengan dipenuhinya unsur-unsur perbuatan yang sudah dirumuskan bukan dengan timbulnya akibat.

Kubu kedua mengatakan, bahwa kata dapat sebelum frase merugikan keuangan negara atau perekonomian negara memang menunjukkan bahwa delik ini merupakan delik formil, yaitu suatu delik yang hanya memfokuskan pada perbuatan tertentu yang dilarang, bukan pada akibat dari

\footnotetext{
${ }^{16}$ Ibid., hal .90-94.

${ }^{17}$ Indonesia, Undang-undang Tentang Pemberantasan Tindak Pidana Korupsi, UU No.20, LN No. 134 Tahun 2001 , TLN No. 4150 penjelasan ps . 2 ayat (1).

${ }^{18}$ R.Wiyono,2009, Pembahasan Undang Undang Pemberantasan Tindak Pidana Korupsi, Ed. 2 Cet. 2, Sinar Grafika, Jakarta, hal. 27.

${ }^{19}$ Nur Basuki Minarni,2009, Penyalahgunaan Wewenang dan Tindak Pidana Korupsi dalam Pengelolaan Keuangan Daerah, Cet Kedua, Laksbang Mediatama, Yogyakarta, hal. 50.
} 
perbuatan itu. Akan tetapi, jika delik ini dimaknai secara formil maka ketentuan dalam Pasal 2 ayat (1) ini jelas bertentangan dengan unsur lain dalam yang sama, yaitu unsur memperkaya diri sendiri orang lain atau suatu korporasi. Sebab unsur ini mensyaratkan bertambahnya kekayaan dari yang tidak ada menjadi ada, atau dari yang sudah ada bertambah ada atau kaya.

Praktik penanganan perkara tindak pidana korupsi cendrung mengikuti pandangan kubu kedua, dimana unsur delik kerugian keuangan negara atau perekonomian negara dihitung secara pasti dengan bantuan ahli, bukan sebatas potensi sebagai mana pandangan kubu pertama. Hal ini sejalan dengan Ringkasan putusan Mahkamah Konstitusi Nomor 003/PUU-IV/2006 menekankan putusan terhadap Pasal 2 ayat (1) dan Pasal 3 UU PTPK yang berkenaan dengan frasa dapat. Mahkamah berpendapat bahwa kerugian keuangan negara harus dibuktikan dan dapat dihitung, meskipun sebagai perkiraan atau estimasi serta kerugian keuangan negara belum terjadi.

Rumusan delik sebagaimana diatur dalam Pasal 2 dan Pasal 3 UUPTPK adalah delik formil, akan tetapi dari kasus-kasus tindak pidana korupsi khususnya yang berkaitan dengan Pasal 2 dan Pasal 3 dalam operasional pelaksanaan penegakan hukumnya umumnya selalu memerlukan pembuktian atau alat bukti realisasi kerugian Negara yang terjadi akibat perbuatan terdakwa. Sehingga rumusan delik dalam UUPTPK Nomor 31 Tahun 1999 tidak singkron dengan operasionalisasi penerapannya,

\section{Rumusan Pidana dan Pemidanaan Tindak Pidana Korupsi yang Merugikan Keuangan Negara.}

Proses legislasi/formulasi merupakan tahap perencanaan awal yang sangat strategis dari proses penegakan hukum "in concerto". ${ }^{20}$ Roeslan Saleh pernah menyatakan bahwa undang-undang merupakan bagian dari suatu kebijaksanaan tertentu, ia tidak hanya alat untuk melaksanakan tetapi juga menentukan, menggariskan atau "merancangkan" suatu kebijaksanaan. ${ }^{21}$

Dalam KUHP yang sekarang diberlakukan, pidana diatur dalam Bab II Pasal 10-43. Berdasarkan Pasal 10 KUHP jenis-jenis pidana adalah pertama pidana pokok, yang terdiri dari pidana mati, pidana penjara, pidana kurungan, pidana denda, dan pidana tutupan. Pidana tutupan merupakan jenis pidana yang " baru " , karena diadakan dengan UU Nomor 20 Tahun 1946 tentang Hukuman Tutupan. Kedua, pidana tambahan yang terdiri dari pencabutan hak-hak tertentu, perampasan barang-barang tertentu, dan pengumuman putusan hakim. Jenis-jenis pidana yang ada dalam KUHP tersebut, dilihat dari segi ilmu hukum pidana, masih mencerminkan pidana yang lebih berorientasi pada " pembalasan " sehingga tampak kaku dan bersifat imperatif dalam pelaksanannya. Sifat kaku dan imperatifnya jenis pidana dan pemidanaan dalam KUHP sangat terlihat dalam pasal-pasal deliknya. Perkembangan dunia hukum pidana secara global, terutama setelah dilakukannya beberapa kali Kongres PBB tentang The Prevention of Crime and the Treatment of Offenders, wacana mengenai hukum pidana mengalami perombakan yang signifikan. ${ }^{22}$

Pembaharuan hukum pidana pada hakekatnya merupakan suatu upaya melakukan peninjauan

\footnotetext{
20 Barda Nawawi Arief,2012,Kebijakan Formulasi Ketentuan Pidana dalam Peraturan Perundang-Undangan.,Pustaka Magister, Semarang.(Selanjutnya disingkat Barda Nawawi Arief I),..hal10.

${ }^{21}$ Ibid., hal. 11

${ }^{22}$ https://www.researchgate.net/publication/315693773 Prinsip Individualisasi Pidana dalam Pembaharuan Hukum Pidana Materiel Indonesia [accessed Jan 10 2018].
} 
dan pembentukan kembali (reorientasi dan reformasi) hukum pidana yang sesuai dengan nilai-nilai sentral sosio-politik, sosio-filosofik, dan nilai-nilai sosio-kultural masyarakat Indonesia. Oleh karena itu, pembaharuan pidana pada hakikatnya harus ditempuh dengan pendekatan yang berorientasi pada kebijakan (policy-oriented approach) dan sekaligus pendekatan yang berorientasi pada nilai (valueoriented approach) ${ }^{23}$. Dengan demikian makna dan hakikat pembaharuan hukum pidana dilihat dari sudut pendekatan kebijakan adalah bagian dari kebijakan sosial (social policy), kebijakan kriminal (criminal policy), dan kebijakan penegakan hukum (law enforcement policy). Ini berarti pembaharuan hukum pidana pada hakikatnya merupakan bagian dari upaya untuk mengatasi masalah-masalah sosial dalam rangka mencapai tujuan nasional, merupakan bagian dari upaya perlindungan masyarakat khususnya penanggulangan kejahatan, dan bagian dari upaya memperbaharui substansi hukum.

Prinsip pertanggungjawaban pidana bersifat pribadi berarti bahwa hanya orang yang bersalah saja yang dapat dikenakan pidana. Pasal 6 Undang-undang No 48 tahun 2009 tentang Kekuasaan Kehakiman menyatakan :

ayat (1) Tidak seorang pun dapat dihadapkan di depan Pengadilan selain daripada yang ditentukan oleh undang-undang.

Ayat (2) Tidak seorang pun dapat dijatuhi pidana, kecuali apabila pengadilan, karena alat pembuktian yang sah menurut undang-undang, mendapat keyakinan bahwa seseorang yang dianggap dapat bertanggungjawab, telah bersalah atas perbuatan yang didakwakan atas dirinya.

Bagaimana perumusan pidana dan pemidanaan dalam Undang-Undang Nomor 31 Tahun 1999 tentang Pemenberantasan Tindak Pidana Korupsi, apakah telah mempertimbangkan pendekatan yang berorientasi pada kebijakan (policy-oriented approach) dan sekaligus pendekatan yang berorientasi pada nilai (value-oriented approach). Rumusan delik pidana yang merugikan keuangan Negara diatur dalam Pasal 2 dan Pasal 3 yang pidana dan rumusannya adalah sebagai berikut:

Pasal 2 :

(1) Setiap orang yang secara melawan hukum melakukan perbuatan memperkaya diri sendiri atau orang lain yang suatu korporasi yang dapat merugikan keuangan negara atau perekonomian negara, dipidana dengan pidana penjara seumur hidup atau pidana penjara paling singkat 4 (empat) tahun dan paling lama 20 (dua puluh) tahun dan denda paling sedikit Rp. 200.000.000.00 (dua ratus juta rupiah) dan paling banyak Rp. 1.000.000.000,00 (satu miliar rupiah).

(2) Dalam hal tindak pidana korupsi sebagaimana dimaksud dalam ayat (1) dilakukan dalam keadaan tertentu pidana mati dapat dijatuhkan.

\section{Pasal 3 :}

Setiap orang yang dengan tujuan menguntungkan diri sendiri atau orang lain atau suatu korporasi, menyalahgunakan kewenangan, kesempatan, atau sarana yang ada padanya karena jabatan atau kedudukan atau sarana yang ada padanya karena jabatan atau kedudukan yang dapat merugikan keuangan negara atau perekonomian negara, dipidana dengan pidana penjara seumur hidup atau pidana penjara paling singkat 1 (satu) tahun dan paling lama 20 (dua puluh) tahun dan atau denda

\footnotetext{
${ }^{23}$ Barda Nawawi Arif,2011, Bunga Rampai Kebijakan Hukum Pidana ,Perdanamedia, Jakarta,(Selanjutnya disingkat Barda Nawawi Arief II)..hal 29.
} 
paling sedikit Rp. 50.000 .000 (lima puluh juta rupiah) dan paling banyak Rp. 1.000.000.000,00 (satu miliar rupiah)

Dari pasal tersebut di atas bahwa perumusan pidana ditentukan pidana minimumnya yang biasanya disebut sebagai minimum kusus. Ancaman pidana minimum khusus menyimpang dari sistem pidana yang diatur dalam KUHP. Dengan dianutnya sistem minimal khusus yang menyimpang dari sistem KUHP maka seharusnya UU khusus di luar KUHP membuat aturan khusus tersendiri untuk penerapannya. Ini merupakan konsekuensi dari adanya Pasal 103 KUHP karena KUHP sendiri belum mengatur hal ini. ${ }^{24}$

Lampiran UU Nomor 1 Tahun 2004 menyatakan :Dalam merumuskan ketentuan pidana perlu diperhatikan asas-asas umum ketentuan pidana yang terdapat dalam Buku Kesatu Kitab UndangUndang Hukum Pidana karena ketenruan dalam Buku Kesatu berlaku juga bagi perbuatann yang dapat dipidanamenurut Peraturan Perundang-Undangan lain, kecuali oleh Undang-Undang ditentukan lain. ${ }^{25}$

Pola rumusan pidana pada Pasal 2 dan Pasal 3 di atas ancaman pidana maksimalnya sama sama 20 (dua puluh) tahun akan tetapi pidana minimum khusus pada masing-masing pasal berbeda yaitu pidana minimal khusus dalam delik pasal 2 empat tahun sedang delik pasal 3 pidana minimal khusus 1 tahun. Sampai saat ini pedoman pemidanaan minimal khusus yang menyimang dari KUHP belum ada sehingga sering terjadi disparitas putusan majelis hakim atas kasus Tindak Pidana Korupsi yang sama.

Disamping pidana pokok dimungkinkan juga kepada terdakwa pelaku tindak pidana korupsi dijatuhkan pidana tambahan. Dalam UUTPK pidana tambahan diatur dalam Pasal 18 yaitu :

Selain pidana tambahan sebagaimana dimaksud dalam Kitab Undang-undang Hukum Pidana, sebagai pidana tambahan adalah:

a. perampasan barang bergerak yang berwujud atau yang tidak berwujud atau barang tidak bergerak yang digunakan untuk atau yang diperoleh dari tindak pidana korupsi, termasuk perusahaan milik terpidana di mana tindak pidana korupsi dilakukan, begitu pula dari barang yang mengantikan barang-barang tersebut;

b. pembayaran uang pengganti yang jumlahnya sebanyak-banyaknya sama dengan harta benda yang diperoleh dari tindak pidana korupsi.

c. Penutupan Seluruh atau sebagian perusahaan untuk waktu paling lama 1 (satu) tahun;

d. Pencabutan Seluruh atau sebagian hak-hak tertentu atau penghapusan Seluruh atau sebagian keuntungan tertentu, yang telah atau dapat diberikan oleh Pemerintah kepada terpidana.

Menurut Sudarto, individualisasi pidana artinya dalam memberikan sanksi pidana selalu memperhatikan sifat-sifat dan keadaan-keadaan si pelaku. Beberapa karakteristik prinsip individualisasi pidana menurut Barda Nawawi Arief adalah : (Barda Nawawi Arief, 1996 : 31)

1. Pertanggungjawaban (pidana) bersifat pribadi/perorangan (asas personal). Orang yang bersalah melakukan tindak pidanalah yang harus bertanggung jawab atas perbuatannya dan tidak dapat diwakili oleh orang lain.

2. Pidana hanya diberikan kepada orang yang bersalah (asas culpabilitas). Hal ini berarti bahwa orang

\footnotetext{
${ }^{24}$ Barda Nawawi Arief, 2010, Masalah Penegakan Hukum dan Kebijakan Hukum Pidana dalam Penanggulangan Kejahatan. Cet 3,(Selanjutnya disingkat Barda Nawawi Arief III).hal.155.

${ }^{25}$ Barda Nawawi Arief I, op.cit.,ha.13.
} 
yang melakukan tindak pidana dengan kesalahanlah yang dapat dipidana. Kesalahan tersebut baik dalam bentuk kesengajaan ataupun kealpaan.

3. Pidana harus disesuaikan dengan karakteristik dan keadaan si pelaku. Hal ini berarti harus ada kelonggaran/fleksibilitas bagi hakim dalam memilih sanksi pidana (jenis maupun berat ringannya pidana) dan harus ada kemungkinan modifikasi pidana (perubahan/penyesuaian) dalam pelaksanaannya.

Dari rumusan pidana pokok dan pidana tambanhan yang ditetapkan dalam UUTPK khusus mengenai ancaman pidana minimum khusus dan uang pengganti yang apabila tidak dapat dipenuhi oleh terdakwa akan diganti dengan pidana penjara. Rumusan pidana ini menyimpangi aturan umum yang telah ditentukan dalam Buku I KUHP, akan tetapi dalam UUPTPK tidak ditur lebihlanjut. Sehingga menimbulkan permasalahan dalam pelaksanaan dan penerapan penegakan hukum khususnya penerapan pemidanaan seperti :

Disparitas putusan

Penentuan pidana penjara sebagai pidana tambahan kalau terdakwa tidak dapat memenuhu uang pengganti

\section{PENUTUP}

Berdasarkan uraian di atas dapat diambil beberapa kesimpulan sebagai berikut

1. Perumusan delik tindak pidana korupsi yang merugikan keuangan Negara dalam UUPTPK Nomor 31 Tahun 1999 tidak sinkron dengan operasionalisasi pelaksanaan penegakan hukum,

2. Kebijakan perumusan pemidanaan delik tindak pidana korupsi yang diatur dalam Pasal 2 dan Pasal 3 belum mempertimbangkan rasa keadilan dan kepatutan bagi perbuatan yang didakwa atas Pasal 2 dengan Pasal 3 UUPTPK.

3. Penjatuhan pidana Tambahan berupa uang pengganti atas kerugian yang dinikmati oleh terpidana yang apabila tidak dapat dikembalikan dikenakan pidana penjara pengganti yang dimuat dalam putusan majelis hakim, merupakan penerapan individualisasi pidana yang diterapkan kepada masing-masing peran dan perbuatan terpidana.

\section{DAFTAR PUSTAKA}

Ali, Mahrus, 2011, Hukum Pidana Korupsi di Indonesia. Yagyakarta: UII Press..

Arief, Barda Nawawi, 2010, Masalah Penegakan Hukum dan Kebijakan Hukum Pidana dalam Penanggulangan Kejahatan. Jakarta: Predanamedia 2011, Bunga Rampai Kebijakan Hukum Pidana Jakarta Predanamedia.

2011, Kebijakan Formulasi Ketentuan Pidana dalam Peraturan Perundang-Undangan, Semarang :Putaka Magister.

B.Carada, Alfredo, 2009, Korupsi Sumber Daya Alam, dan Isu Lingkungan, Korupsi Mengorupsi Indonesia. Jakarta: Gramedia Pustaka..

Chazawi, Adami, 2008, Hukum Pembuktian Tindak Pidana Korupsi. Bandung: PT Alumni.. 
Harahap, M.Yahya, 2006, Pembahasan Permasalahan dan Penerapan KUHAP. Jakarta:Sinar Grafika..

Juni Sjafrien Jahja, 2013, Prinsip Kehati-hatian dalam Memberantas Manajemen Koruptif pada Pemerintahan \& Korporasi

Kaligis, O.C, 2008, Pendapat Ahli Dalam Perkara Pidana. Bandung: PT Alumni..

M.Tuanakotta, Theodorus, 2010, Akuntansi Forensik \& Audit Investigatif. Jakarta: Salemba Empat..

Mardjono Reksodiputro, 1993, Sistem Peradilan Pidana Indonesia (Melihat Kepada Kejahatan Dan Penegakan Hukum Dalam Batas - Batas Toleransi), Fakultas Hukum Unversitas Indonesia.

Marwan Efendi,2010. Pemberantasan Korupsi dan Good Goernance, PT Timpani Publishing.

Mulyadi, Lilik, 2007, Putusan hakim dalam Hukum Acara Pidana. Bandung: PT Citra Aditya Banti.. 2011,Tindak Pidana Korupsi di Indonesia: Normatis, Teoritis, Praktik dan Masalahnya. Bandung: PT Alumni..

Sulaiman, Alfin, 2011, Keuangan Negara Pada Badan Usaha Milik Negara Dalam Perspektif Ilmu Hukum. Bandung: PT Alumni..

Wiyono, R, 2009, Pembahasan Undang-Undang Pemberantasan Tindak Pidana Korupsi.Jakarta: Sinar Grafika.. 